\title{
Temporary Freshwater Pond Quality and Properties: A Potential indicator of the Health Level of Environment
}

\author{
Zongo Bilassé ${ }^{1}$ and Boussim Issaka Joseph ${ }^{2 *}$ \\ ${ }^{1}$ Department of Biological Sciences, Université Polytechnique de Bobo-Dioulasso, Burkina Faso \\ ${ }^{2}$ Department of Biology and Physiology of Plants, Université OuagaI, Burkina Faso
}

Submission: February 05, 2017; Published: May 31, 2017

*Corresponding author: Boussim Issaka Joseph, Department of Biology and Physiology of Plants, Université Ouagal Joseph Ki-Zerbo, 03 B.P. 7021 Ouagadougou 03, Burkina Faso, Tel: +22670265755; Fax: +22650307242; Email: ijboussim@gmail.com

Abstract

Climate change and human activities are major factors of ecosystem degradation. This degradation is more remarkable with aquatic ecosystems because of the high vulnerability of water bodies. With reduced size, temporary pond water is easily contaminated and polluted by climatic factors and the effect of human activities.

Investigations were conducted in temporary ponds of Burkina Faso and Benin during rainy seasons of 2007, 2008 and 2009. In Burkina Faso, natural temporary ponds were selected in the sudanian and the sahelian zones of the eastern part of the country but also including protected areas and unprotected areas. In Benin, investigations were conducted at the northern part of the country using artificial temporary ponds of 14 days cycle. The aim of the study was to analyze the relationship between freshwater pond water quality and environment health after measuring the physical, chemical and biological properties of temporary ponds.

The analyses showed that physico-chemical properties of temporary ponds were found to be strongly degraded by climate factors and human activities and thereby conducting to the growth of harmful and pathogenic microorganisms leading to a public health problem. Temporary ponds were strongly sensitive to any impact on the environment because of their small size. Determining temporary pond water quality can help to evaluate the pollution and the health level of environments and plan efficient measures to protect environment and human health.

Keywords: Temporary ponds; Water quality properties; Microalgae; Environment; Microorganisms

\section{Introduction}

Climate change and human activities are major factors of ecosystem degradation. Aquatic ecosystems are more sensitive to the impact of the different factors because of the high vulnerability of water bodies and particularly when their sizes are reduced as temporary pond systems. Change in the climatic parameters and human activities lead to the change in the physical, the chemical and biological properties of aquatic ecosystems. Change in the physico-chemical and microbial threats create serious problems for drinking water for human and cattle, for agricultural products coming from watering farms. In many parts of the world especially in less developed countries, many temporary ponds exist. In these countries, the increasing human needs and activities leads to the rapid degradation and pollution of temporary ponds that are only supplied in water during rainy season, either directly by precipitations or by runoff waters draining with them a major part of organic matters accumulated during dry seasons into basins [1]. However, in the areas with high density of plants and high land cover, temporary ponds are protected against matter contaminations due to the reduction of erosion and sediment. Water transparency is then low while salinity and nutrient concentration is high outside reserves [1]. This is due to the impact of human activities [2,3] such as agriculture, industry, toilets and dishes washing which provide huge nutrients to ponds and other aquatic ecosystems with less impact on those from the environment of protected areas. The deterioration and pollution of pond environment is characterized by the degradation of physical and chemical parameters of ponds, accentuated by the growth of harmful and pathogenic organisms (bacteria, protozoa, viruses, and harmful algae) exposing people to many diseases [3]. In this study, the 
relationship between freshwater ponds quality and environment health was analyzed. The variation of the physical and chemical parameters of ponds water according to an anthropogenic and climatic gradients was measured, microalgae proliferation and the impact of physico-chemical parameters on algae in pond water were estimated.

\section{Material and Methods}

Investigations were conducted in temporary ponds of subSaharan areas (Burkina Faso and Benin) during rainy seasons of 2007, 2008 and 2009. In Burkina Faso, natural temporary ponds were selected in the sudanian and the sahelian zones of the eastern part of the country for investigations. Temporary ponds in these zones included ponds of protected areas and unprotected areas [1]. Parameters such as Water pH, electrical conductivity (salinity), transparency, pond depth, total nutrient (nitrates, phosphates-phosphorus and ammonium) were measured. In Benin, investigations were conducted at the northern part of the country using artificial temporary ponds containing assemblages of tadpoles of Hoplobatrachus occipitalis, Kassina fusca, Ptychadena bibroni, Phrynomantis microps species. Artificial ponds were placed in the village of Batia next to Pendjari reserve $[4,5]$ and the same physical and chemical parameters were also measured during experimentations of 14 days cycle.

Collections of samples were realized in the open water of natural ponds as well as artificial ponds using a tube of $120 \mathrm{ml}$ following the procedure implemented by Zongo [6]. Samples of each were transferred into collection bottles [7] and immediately preserved with $5 \%$ formalin at ambient temperature. Algae species were identified following species identification procedure as described by Zongo et al. [7] and using the taxonomical criterias of algae base [8].

Algal biomass in ponds water was assessed by the relative abundances of algae determined in sub samples ( $5 \mathrm{ml} / \mathrm{sample}$ ). Relative abundances of algae in each sub sample are determined using Fuch-Rosenthal chamber [9]. The chamber was filled with homogeneous sub-sample and kept undisturbed for 5 minutes to allow particles settling [10]. After settling, all individuals in the chamber were counted. A repetitive counting of individuals in the chamber was done four times for each sample and the relative mean abundances of algae were determined [1].

\section{Results and Discussions}

\section{Water variables and microflora in temporary freshwater ponds}

The physical and chemical properties of water are central to the physiology and ecology of freshwater organisms [5]. The different physico-chemical properties of temporary ponds were found to be strongly affected by climate factors and human activities and thereby affecting the growth rate of microalgae and other microorganisms. Among microalgae biomass, chlorophytes were most represented in natural ponds as well as in artificial ponds during the study period. In artificial ponds, they were positively affected by water variables such as $\mathrm{pH}$ $(p=0.006)$, water transparency $(0.015)$, water depth $(p=0.000)$, the concentrations of nitrates $(\mathrm{p}=0.044)$, phosphates $(\mathrm{p}=0.040)$ and ammonium $(p=0.017)$ and the temperature $(p=0.002)$ of water. Tadpole assemblages had the ability to purify water and increasing water clarity because of their filtering, feeding, detritivorous and herbivorous functions in temporary ponds [4].

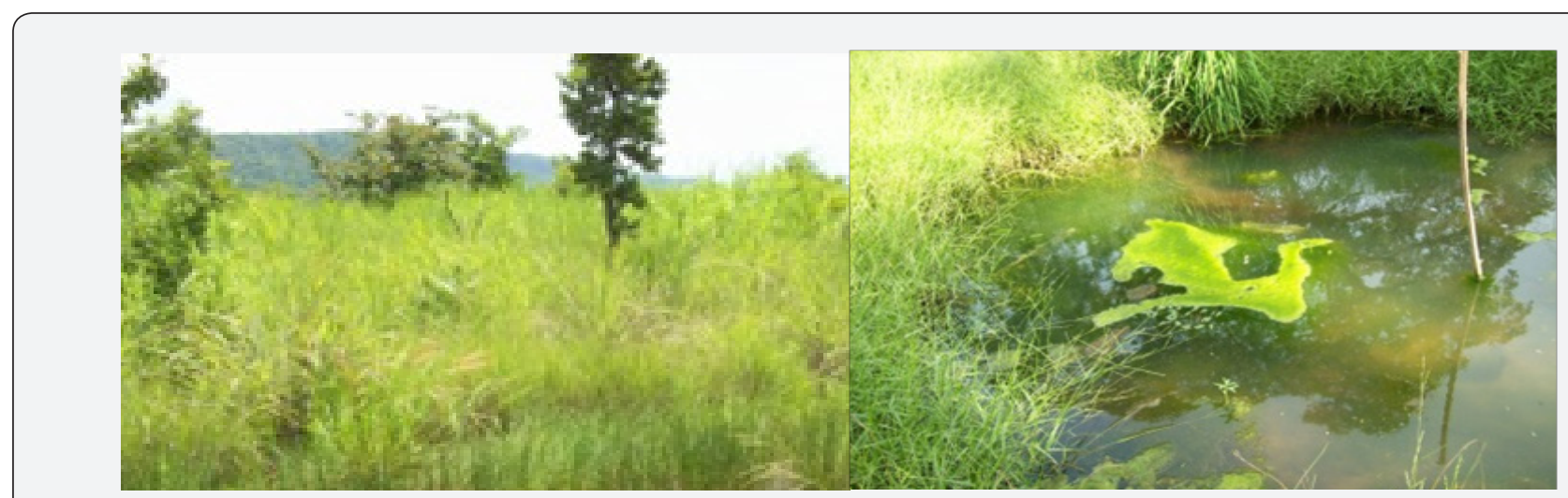

Figure 1: Algae biomass of ponds in protected areas and those in unprotected areas. a: pond in protected areas (reserves); b: pond in unprotected areas (outside reserve: villages). Source: Zongo et al. [1].

The natural ponds were however on a physical pressure conducting to the increasing of pond size and disturbance of water quality. Furthermore, they were supplied in organic matter from human activities and going into temporary ponds by runoffs. Those runoffs are the major factors that enriched ponds in nutrients [11] by bringing residues and organic matters and justifying an important growth of cyanobacteria and euglenoid species in ponds. Cyanobacteria species belonged to the genera such as Aphanocapsa, Mycrocytis, Aphanothece, Chroococcus, Snowella, Lynbya, Oscillatoria, Phormidium, Planktothrix, and Pseudonabaena and euglenoid species belonged to Trachelomonas, Strombomonas, Euglena, Phacusgenera [11]. The excessive development of microalgae including harmful algae could explain also the growth of possible pathogenic bacteria, viruses and protozoa in temporary ponds. In aquifers into which livestock wastewater, with its diverse microflora, is introduced, 
the diversity of the bacterial community may greatly increase [12]. In contrary, Bacterial-community diversity generally is low under stressed conditions and chemical contaminants [13]. Indeed, the variation in water temperature and nutrient concentration caused by climate change and particularly human activities lead to a decay in some bacteria growth that normally plays important role in the degradation of organic matter, the regulation of algae growth in water systems. Thus disturbance conduct to more pollution of water. This situation was observed during this study in temporary ponds located in villages and fields where intensive farming and breeding are practiced for livelihood. Consequently, they are disturbed because contaminated by chemical products (fertilizers, pesticides, herbicides) and important organic matter from cattle manure (Figure 1).

\section{Pond water quality and environment health}

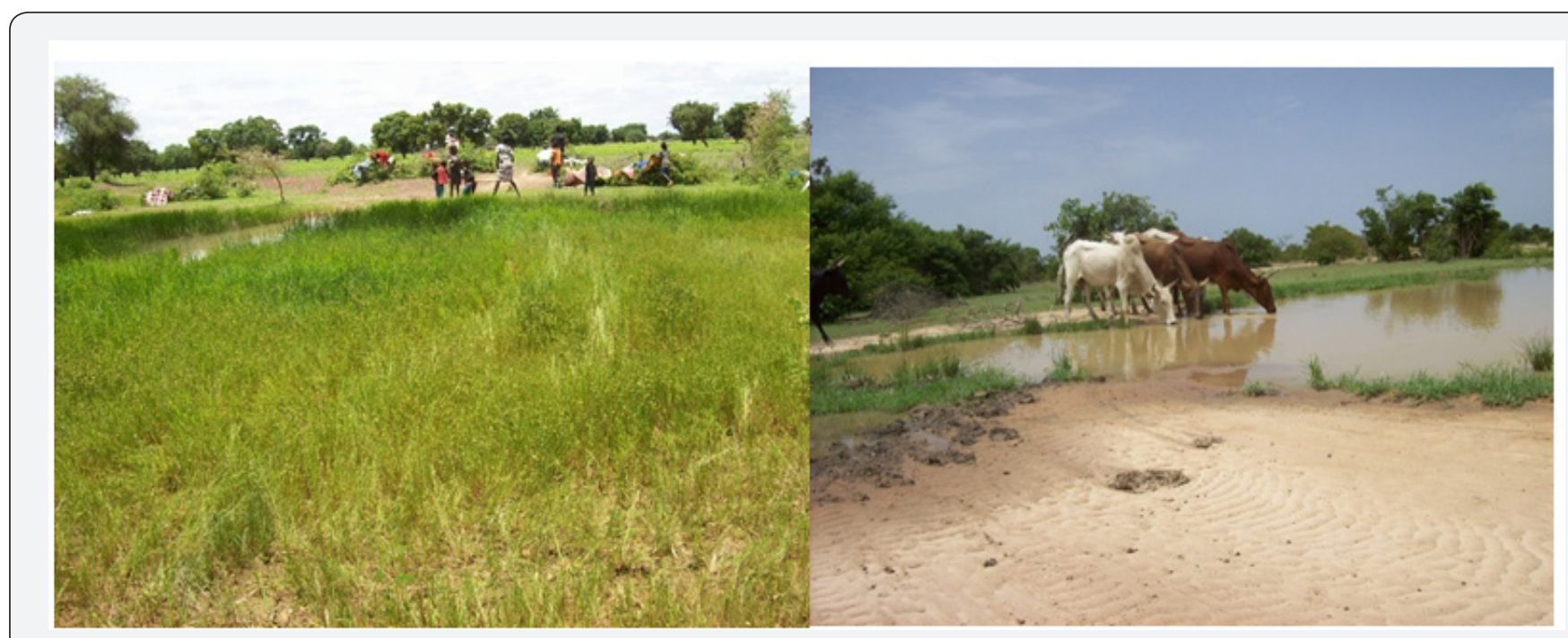

Figure 2: Utilisation of pond wastewater for washing, swimming (a) and livestock watering (b).

Temporary pond water quality was found to be more affected by climate factors and human activities in unprotected areas. In unprotected areas and even in disturbed protected areas, pond water was strongly deteriorated conducting to the growing of harmful algae [14-16] and other pathogenic organisms. The presence of pathogenic organisms in temporary ponds negatively affect the development of aquatic fauna such as tadpoles. The reduction of aquatic fauna and their ecological role of water cleaninig lead to more degradation of water systems. The excessive growth of microalgae in ponds of villages compared to forest ponds (Figure 2) indicate a real disturbance of environment in unprotected areas. The sustainable forest management is essential to ensure the supply of good-quality fresh water, provide protection from natural hazards such as flooding or soil erosion and to protect the needs of aquatic species [17]. Forest management seem to not be only enough for all environment protection. Environment all over the world need to be protected by reducing the sources of contaminations and pollutions.

\section{Degradation of pond water quality and related consequences on populations}

The pollution and disturbance of ecosystems suppose the environment degradation where these ecosystems are found. The disturbance of ecosystems is characterized by the excessive growth of harmful and pathogenic organisms (bacteria, viruses, protozoa and harmful algae). In western Africa and particularly in Benin and Burkina Faso, because of problem to access safe water, contaminated water resources from temporary ponds is used by populations for multiple purposes such as drinking, cooking, toilets, swimming, watering (Figure $2 \mathrm{~b}$ ) and exposing themselves to such water diseases. This situation becomes a serious health problem in West-African countries and particularly Burkina Faso and Benin [1]. Indeed, the contamination and pollution of ecosystems expose people who use natural resources to many water-associated diseases $[3,18]$. Multiple diseases (e.g., Gastrointestinal illness with symptoms such as diarrhea, nausea, vomiting, fever, abdominal pain; Schistosomiasis; Salmonellosis; Guinea worm disease; malaria; cholera) caused by microbes and germs were reported in developing countries of Africa during previous studies $[18,19]$.

\section{Conclusion}

1. Climatic and anthropogenic factors are major causes in the disturbance of environmental structure and functioning accentuated by increasing human needs and activities. That also contributes to enhance climate change.

2. Because of the small size of temporary ponds, they are easily affected by any source of disturbance in 
the environment. The physical, chemical and biological parameters rapidly vary due to climate change and the impact of human activity.

3. Determining pond water quality is a good tool to knowing the real causes of disturbance and evaluating the pollution and health level of environments. The knowledge of the main causes could help to take the real measures for a reduction of factors of disturbance and a sustainable protection of environment.

\section{Acknowledgement}

This study was funded by the BIOLOG-program of the German Ministry of Education and Science $(B M B+F$; Project BIOTA III, amphibians). The authors particularly thank Mark-Oliver Rödel, Adjima Thiombiano for their support. They are thankful to MeikeMohneke, ThiombianoAhandi and Kaboréjérémy for their help during the field work.

\section{References}

1. Zongo B, Zongo F, Toguyeni A, Boussim IJ (2017) Water quality in forest and village ponds in Burkina Faso (Western Africa). J forest Res, pp. $1-10$.

2. Hart BT, Maher B, Lawrence I (1999) New generation water quality guidelines for ecosystem protection. Freshw Biol 41(2): 347-359.

3. Johnson B, Bachelar-Nicaulo P, Okibe N, Thomas A, Hallberg KB (2009) Ferrimicrobium acidiphilum gen. nov., sp. nov.and Ferrithrix thermotolerans gen. nov., sp. nov.: heterotrophic, ironoxidizing extremely acidophilic actinobacteria. Int J Syst Evol Microbiol 59(Pt 5): 1082-1089.

4. Zongo B, Boussim IJ (2015) The effects of physicochemical variables and tadpole assemblages on microalgal communities in freshwater temporary ponds through an experimental approach. Aquatic Biosystems 11(1): 1-14.

5. Sigee DC (2005) Freshwater microbiology. Biodynamic and dynamic interactions of microorganisms in the aquatic environments. John Wiley \& Sons Ltd., USA, pp. 544.

6. Zongo B (2011) Communautés micro-algales dans les marestemporaires, interactions avec variables physico-chimiques et assemblage de têtards en Afrique de l'Ouest. These de Doctorat, Univ Ouaga, Burkina Faso.
7. Zongo B, Zongo F, Ouattara A, Boussim IJ (2011) A taxonomic study of the genus Closterium Nitzsch (Zygnematophyceae, Streptophyta) in temporary ponds (Burkina Faso, West Africa). Cryptogamie Algol 32(3): 255-270.

8. algaebase.org. Data base of information on algae that includes terrestrial, marine and freshwater organisms.

9. Wéry M (1995) Protozoologie médicale. Agence Universitaire de la francophonie, De Boeck \& Larcier SA, Bruxelles, Belgium.

10. Kouri T, Gyory A, Rowan RM, ISLH Urinalysis Task Force (2003) ISLH Recommended Reference Procedure for the Enumeration of Particles in Urine. Lab Hematol 9(2): 58-63.

11.Zongo B, Zongo F (2016) Microalgae Community Composition in Tropical Temporary Freshwater Ponds of Burkina Faso (West Africa). Am J Agric Sci 3(5): 72-84.

12. Cho JC, Kim SJ (2000) Increase in Bacterial community diversity in subsurface aquifers receiving livestock wastewater input. Appl Environ Microbiol 66(3): 956-965.

13. Atlas RM, Horowitz A, Krichevsky M, Bej AK (1991) Response of microbial populations to environmental disturbance. Microb Ecol 22(1): 249-256.

14. Leflaive J, Ten-Have L (2007) Algal and cyanbacterial secondary metabolites in freshwaters: a comparison of allelopathic compounds and toxins. Freshwater Biol 52(2): 199-214.

15. Mankiewicz-Boczek J, Urbaniak M, Romanowska-Duka Z, Izydorczyk K (2006) Toxic cyanobacteria strains in lowland Dam Reservoir (Sulejów Res., Central Poland): amplification of MCY genes for detection and identification. Pol J Ecol 54(2): 171-180.

16. Ballot A, Krienitz L, Kotut K, Wiegrand C, Pflugmacher S (2005) Cyanobacteria and cyanobacterial toxins in alkaline crater lakes Sonachi and Simbi, Kenya. Harmful Algae 4(1): 139-150.

17. Forestry commission (2011) Introduction to forests and water. In Forests and water: UK forestry standard guidelines. Sylvan House, Edinburgh, UK, pp. 7-14.

18. Pandey PK, Kass PH, Soupir ML, Biswas S, Singh VP (2014) Contamination of water resources by pathogenic bacteria. AMB Express 4: 51

19. Arnone RD, Walling JP (2007) Waterborne pathogens in urban watersheds. J Water Health 5(1): 149-162.

\section{Your next submission with Juniper Publishers will reach you the below assets}

- Quality Editorial service

- Swift Peer Review

- Reprints availability

- E-prints Service

- Manuscript Podcast for convenient understanding

- Global attainment for your research

- Manuscript accessibility in different formats

( Pdf, E-pub, Full Text, Audio)

- Unceasing customer service

\section{Track the below URL for one-step submission}

https://juniperpublishers.com/online-submission.php 